\title{
Pola Asuh Orang Tua Dalam Meningkatkan Kedisiplinan Pendidikan Anak (Studi Deskriptif di Kelurahan Rabadompu Timur Kecamatan Raba Kota Bima)
}

\author{
Ida Waluyati \\ Program Studi Pendidikan Sosiologi STKIP Bima \\ Jalan Piere Tendean Kel. Mande Tlp.Fax (0374) 42801, Bima 84191, Indonesia \\ email; idawaluyati81@gmail.com
}

\begin{abstract}
Abstrak
Tujuan penelitian ini adalah 1) untuk mendeskripsikan bagaimana pola asuh yang diterapkan oleh orang tua dalam meningkatkan kedisiplinan pendidikan anak di Kelurahan Rabadompu Timur Kecamatan Raba Kota Bima, 2) untuk mendeskripsikan kendala-kendala apa saja yang dihadapi oleh orang tua dalam meningkatkan kedisiplinan pendidikan anak di Kelurahan Rabadompu Timur Kecamatan Raba Kota Bima.

Penelitian ini menggunakan pendekatan deskriptif kualitatif. Subjek penelitian ini adalah orang tua dan anak di Kelurahan Rabadompu Timur Kecamatan Raba Kota Bima. Informan utama dalam penelitian ini adalah orang tua sejumlah 12 orang dan anak sejumlah 8 orang. Teknik pengumpulan data yang digunakan adalah observasi, wawancara, dan dokumentasi. Instrumen penelitian adalah berupa pedoman wawancara dan pedoman observasi. Teknik analisis data meliputi 3 (tiga) tahap yaitu reduksi data, penyajian (display) data, dan verifikasi data.

Hasil penelitian ini menunjukkan bahwa 1) pola asuh orang tua dalam meningkatkan disiplin pendidikan anak di Kelurahan Rabadompu Timur Kecamatan Raba Kota Bima adalah ditemukan 3 (tiga) bentuk pola asuh yaitu pola asuh otoriter, permisif, dan demokratif, 2) kendala yang dihadapi oleh orang tua dalam mendidik kedisiplinan pendidikan anak-anaknya yaitu kendala intern (dari dalam keluarga) yaitu kesibukan orang tua dan kurangnya waktu berkumpul dengan keluarga. sedangkan kendala ekstern (di luar keluarga) yaitu pesatnya arus globalisasi, yaitu adanya pengaruh media sosial dan televisi, pengaruh lingkungan sekitar dan teman sepergaulan anak. Oleh sebab itu, diharapkan orang tua harus setiap hari berkomunikasi dan mengontrol pergaulan anak.
\end{abstract}

Kata Kunci: Pola Asuh, Kedisiplinan, Pendidikan Anak 


\section{Pendahuluan}

Komitmen nasional tentang perlunya pendidikan karakter secara imperatif telah tertuang dalam UndangUndang Nomor 20 Tahun 2003 tentang Sistem Pendidikan Nasional. Pasal 3 UU tersebut menyatakan bahwa "Pendidikan nasional berfungsi mengembangkan kemampuan dan membentuk watak serta peradaban bangsa yang bermartabat dalam rangka mencerdaskan kehidupan bangsa, bertujuan untuk berkembangnya potensi peserta didik agar menjadi manusia yang beriman dan bertakwa kepada Tuhan Yang Maha Esa, berakhlak mulia, sehat, berilmu, cakap, kreatif, mandiri, dan menjadi warga negara yang demokratis serta bertanggung jawab". Jika dicermati lima dari delapan potensi peserta didik yang ingin dikembangkan sangat terkait erat dengan pendidikan karakter.

Karakter terpuji merupakan hasil internalisasi nilai-nilai moral pada diri seseorang yang ditandai oleh sikap dan perilaku positif. Oleh karena itu, ia sangat terkait dengan daya kalbu. Ilmu pengetahuan tidak sepenuhnya mampu menciptakan akhlak mulia atau iman, ia hanya mampu mengukuhkannya, dan karena itu pula mengasuh kalbu sambil mengasah nalar akan memperkukuhkan karakter seseorang.

Keluarga menjadi basis utama dalam pembentukan karakter. Tugas membangun karakter juga haruslah menjadi tugas besar bersama antara keluarga, lembaga pendidikan, dan masyarakat. Sejak awal, sifat-sifat baik seperti rasa hormat, peduli, jujur, disiplin, patriotik, rela berkorban, tulus, tanggung jawab, penghargaan diri, toleransi, an lain-lain harus disuntikkan kedalam jiwa anak. Pembentukan karakter harus disertai dengan pembiasaan (habituation) keteladanan (modelling).

Keluarga selalu mempengaruhi pertumbuhan budi pekerti tiap-tiap manusia. Di samping itu, orang tua dapat menanamkan benih kebatinan pada diri anak. Sehubungan dengan ini, disiplin diri sangat diperlukan bagi anak agar memiliki budi pekerti yang baik.

Disiplin sangat penting artinya bagi perkembangan anak. Dengan mengenal aturan-aturan, anak akan merasa lebih aman karena mereka tahu dengan pasti perbuatan mana yang boleh dan mana yang tidak boleh dilakukan. Apabila aturan-aturan telah tertanam, anak akan berusaha menghindari perbuatanperbuatan terlarang dan cenderung melakukan hal-hal yang dianjurkan.

Keutuhan orang tua dalam sebuah keluarga sangat dibutuhkan dalam membantu anak untuk memiliki dan mengembangkan dasar-dasar disiplin pada anak. Orang tua harus memperhatikan kegiatan anak seharihari. Pada tahap ini, merupakan peluang yang tepat bagi orang tua untuk memberikan dasar-dasar pendidikan disiplin pada anak. Dimulai dari tahap ini anak dilatih disiplin waktu, disiplin dalam belajar dan disiplin dalam beribadah. Anak diberikan batasanbatasan dan penjelasan terhadap segala sesuatu yang dilaksanakannya. Dengan demikian, anak akan terbiasa melakukannya dan mempunyai tanggung jawab dalam segala aktivitas sehari-hari.

Keluarga merupakan pusat pendidikan yang pertama dan utama dalam masyarakat, karena dalam keluargalah manusia dilahirkan. Bentuk, isi dan cara-cara pendidikan didalam keluarga akan selalu mempengaruhi tumbuh dan berkembangnya budi pekerti dan kepribadian tiap-tiap 
manusia. Dengan demikian, orang tua mempunyai tanggung jawab dalam membimbing dan mengarahkan agar anak berdisiplin baik dalam melaksanakan hubungan dengan Tuhan, dirinya sendiri, sesama manusia dan lingkungan alam dan makhluk hidup lainnya bedasarkan nilai moral.

Hubungan pola asuh orang tua dengan disiplin anak dimaksudkan sebagai upaya orang tua dalam mengasuh, mengarahkan, membimbing, memimpin dan meletakkan dasar-dasar disiplin diri kepada anak. Disiplin tidak terjadi dengan sendirinya, melainkan harus ditumbuhkan, dibina dan dikembangkan melalui latihan pendidikan atau penanaman kebiasan dengan keteladanan-keteladanan tertentu yang harus dimulai sejak ada dalam lingkungan keluarga sehingga ketika berada di luar lingkungan, anak akan terbiasa mentaati aturan atau norma yang berlaku pada lingkungan tersebut. Apabila kedisiplinan sudah menyatu dalam dirinya, maka sikap atau perbuatan yang dilakukan bukan lagi dirasakan sebagai beban. Nilai-nilai kepatuhan telah menjadi bagian perilaku dalam kehidupannya. Dengan belajar disiplin anak akan mampu menyaring kecanggihan ilmu pengetahuan dan teknologi yaitu teknologi mana yang bermanfaat bagi perkembangan ilmu pengetahuan dan bagi dirinya, serta teknologi mana yang akan merugikan masa depannya.

Hasil studi pendahuluan awal di Kelurahan Rabadompu Timur lebih khusus di lingkungan Nggaro Kumbe pada bulan Pebruari, Tahun 2019 menunjukkan bahwa dalam meningkatkan kedisiplinan anak, orang tua menggunakan pola asuh yang berbeda-beda sesuai dengan tingkat pendidikan orang tua dan usia anak.
Pola asuh anak dari petani cenderung dibiarkan bebas karena kesibukan orang tua di sawah. Sedangkan pola asuh dari orang tua yang berprofesi sebagai PNS cenderung sering meninggalkan anaknya tanpa pengawasan ketat orang tuanya. Oleh karena itu, penelitian ini difokuskan pada pola asuh orang tua dalam meningkatkan kedisiplinan pendidikan anak (studi deskriptif di Kelurahan Rabadompu Timur Kecamatan Raba Kota Bima).

\section{Metode Penelitian}

Penelitian ini menggunakan pendekatan deskriptif kualitatif. Variabel dalam penelitian ini yaitu pola asuh orang tua dalam meningkatkan kedisiplinan pendidikan anak. Penelitian ini dilaksanakan selama dua bulan yaitu mulai bulan Maret sampai dengan April 2019. Subjek penelitian ini adalah orang tua dan anak di lingkungan Nggaro Kumbe Kelurahan Rabadompu Timur Kecamatan Raba Kota Bima. Informan utama adalah orang tua sejumlah 12 orang dan sejumlah 8 orang anak. Teknik pengumpulan data yang digunakan adalah observasi, wawancara, dan dokumentasi. Instrumen penelitian adalah pedoman observasi dan pedoman wawancara. Teknik analisis data meliputi tiga tahap yaitu reduksi data, penyajian data, dan verifikasi data.

\section{Hasil Penelitian dan Pembahasan} bahwa:

Hasil penelitian ini menunjukkan

a. Pola asuh orang tua dalam meningkatkan kedisiplinan pendidikan anak yang ditemukan dalam penelitian ini adalah sebagai berikut :

1. Pola asuh otoriter

2. Pola asuh demokratif

3. Pola asuh permisif 
b. Kendala-kendala yang dihadapi orang tua dalam meningkatkan kedisiplinan anak yang ditemukan dalam penelitian ini adalah:

1. Kendala intern adalah :

a. Kesibukkan orang tua

b. Kurangnya waktu berkumpul keluarga

2. Kendala ekstern adalah :

a. Pesatnya arus globalisasi seperti televisi dan tab

b. Pengaruh lingkungan sekitar

Hasil wawancara dengan responden menunjukkan bahwa orang tua di kelurahan Rabadompu Timur Kecamatan Raba Kota Bima dalam meningkatkan kedisiplinan pendidikan anak menggunakan pola asuh yang berbeda-beda sesuai dengan tingkat pendidikan orang tua dan usia anak.

Orang tua yang mempunyai anak kelas 1 sampai dengan kelas 3 Sekolah Dasar dalam meningkatkan disiplin kepada anak menerapkan pola asuh yang otoriter dengan pembiasaan hukuman. Anak di Kelurahan Rabadompu Timur dituntut untuk mengikuti setiap aturan yang dibuat oleh orang tuanya, jika tidak dilaksanakan hukuman akan diberikan oleh orang tua kepada anak tersebut. Hasil penelitian ini sesuai dengan pendapat Maurice Balson (1987) yang menyatakan bahwa dalam pola suh yang otoriter biasanya pihak orangt tua yang menggariskan keputusan-keputusan tentang perilaku anak-anaknya.

Pola asuh ini bercirikan dengan adanya aturan-aturan yang kaku dari orang tua. Kebebasan anak dibatasi oleh orang tua, sehingga aturan yang ada dalam pergaulan keluarga terasa kaku sebab orang tua selalu memaksakan untuk berperilaku sesuai dengan keinginan orang tua. Bila aturan-aturan yang berlaku dilanggar, orang tua akan memberi hukuman kepada anaknya, namun jika akan mematuhinya orang tua tidak memberikan hadiah atau pujian karena yang dilakukan anak sudah sepantasnya dilakukan.

Padahal seorang anak pada tahap ini masih membutuhkan pengawasan yang sangat ketat karena dia belum mengetahui mana perbuatan yang boleh dilakukan dan tidak membahayakan dirinya, mana perbuatan yang tidak boleh dilakukan. Dalam berbuat atau melaksanakan sesuatu sesuai dengan keinginan hatinya, kalau dia senang dan ingin tahu atau penasaran, dia akan melakukan perbuatan tersebut. Akan tetapi bila mereka tidak suka, mereka tidak akan melakukannya.

Memang orang tua yang mempunyai anak kelas 1 sampai dengan kelas 3 Sekolah Dasar ini dalam memberikan dasar-dasar pendidikan disiplin pada anak, menerapkan pola asuh yang otoriter. Namun otoriter disini dalam batasan-batasan tertentu yaitu dalam melatih kedisplinan anak belajar, beribadah, disiplin dalam mengerjakan pekerjaan rumah dan disiplin mentaati peraturan dalam keluarga. Orang tua disini tidak selamanya otoriter dan mengekang segala aktivitas anak, namun anak dalam beraktivitas mendapatkan batasan-batasan dan pengawasan dari orang tua.

Dalam memberikan dasar-dasar pendidikan disiplin pada anak kelas 1 sampai dengan kelas 3 Sekolah Dasar tersebut, selain dengan menerapkan pola asuh yang ketat, orang tua juga memberikan hukuman pada anak. Namun dalam memberikan hukuman harus bijaksana jangan sampai pemberian hukuman tersebut menjadi rangsangan anak untuk berbuat, bukan maksud dan tujuan mengapa tindakan itu dilakukan atau anak merasa 
ketakutan karena terlalu diberikan kekerasan.

Berikut ini ditampilkan data hasil penelitian yang sudah dirancang dalam skema penelitian adalah sebagai berikut

Pola asuh orang tua dalam meningkatkan kedisiplinan pendidikan anak (studi deskriptif di kelurahan Rabadompu Timur Kecamatan Raba Kota Bima)

\begin{tabular}{|l|l|}
\hline \multicolumn{1}{|c|}{} & \multicolumn{1}{|c|}{} \\
\hline $\begin{array}{l}\text { Pola asuh orang } \\
\text { tua dalam } \\
\text { meningkatkan } \\
\text { kedisiplinan } \\
\text { pendidikan anak }\end{array}$ & $\begin{array}{l}\text { Kendala-kendala } \\
\text { orang tua dalam } \\
\text { meningkatkan } \\
\text { kedisiplinan } \\
\text { pendidikan anak }\end{array}$ \\
\hline \begin{tabular}{l|l|}
\hline \multicolumn{1}{|c|}{$\begin{array}{l}\text { Pola asuh orang } \\
\text { tua : } \\
\text { 1. Pola asuh } \\
\text { otoriter }\end{array}$} \\
$\begin{array}{l}\text { 2. Permisif, dan } \\
\text { 3. demokratif }\end{array}$
\end{tabular} & $\begin{array}{l}\text { Kendala-kendala } \\
\text { orang tua : } \\
\text { 1. Kendala intern } \\
\text { 2. Kendala ekstern }\end{array}$ \\
\hline
\end{tabular}

Bagan 1. Skema Hasil Penelitian

Di bawah ini akan diuraikan tentang hasil yang sudah disederhanakan di atas yang berkaitan dengan pola asuh orang tua dalam meningkatkan kedisiplinan pendidikan anak sebagai berikut :

a. Pola asuh orang tua dalam meningkatkan kedisiplinan pendidikan anak yang ditemukan dalam penelitian ini adalah sebagai berikut :

1. Pola asuh otoriter

Yaitu pola asuh dimana orang tua menjadi pusat dalam rumah tangga, orang tua membuat aturan-aturan yang harus diikuti oleh anak, jika tidak diikuti orang tua akan memberikan hukuman baik berupa peringatan ataupun langsung main tangan. Orang tuanya cenderung keras.

2. Pola asuh permisif

Yaitu pola asuh dimana orang tua yang memberikan kebebasan pada anak untuk berbuat sekendak hatinya. Keputusan diserahkan sepenuhnya pada anak, orang tua tidak memberikan pertimbangan apakah tindakan yang ia kerjakan salah atau benar.

3. Pola asuh demokratis

Yaitu pola asuh yang memberi kebebasan pada anak untuk memilih jalan hidupnya, namun orang tua tetap mengontrol dan melihat perkembangan dan kegiatan anaknya.

b. Kendala-kendala yang dihadapi orang tua dalam meningkatkan kedisiplinan pendidikan anak yang ditemukan dalam penelitian ini adalah sebagai berikut :

1. Kendala intern

Kendala intern diartikan sebagai suatu hambatan yang diakibatkan oleh faktor dari dalam keluarga dalam hal ini orang tua. Adapun kendala intern yang dimaksud antara lain adalah :

a. Kesibukan orang tua.

Salah satu kendala yang dihadapi orang tua di Kelurahan Rabadompu Timur Kecamatan Raba Kota Bima adalah kesibukan dalam pekerjaan, sehingga orang tua tidak bisa melatih anakanaknya supaya disiplin dalam belajar dan beribadah. Padahal bimbingan dan kontrol orang tua sangat dibutuhkan bagi anak.

b. Kurangnya waktu berkumpul dengan keluarga. 
Orang tua terlalu banyak menghabiskan waktunya di luar rumah sehingga tidak memiliki waktu yang banyak bersama keluarga, sehingga anak sehari-hari kurang terkontrol dapat menjadi kendala dalam mendidik dan mengasuh anak supaya anak memiliki disiplin diri.

2. Kendala ekstern

Kendala ekstern yaitu suatu hambatan yang dihadapi oleh orang tua karena pengaruh dari luar atau lingkungan. Adapun kendala ekstern tersebut antara lain adalah :

a. Pesatnya arus globalisasi seperti televisi dan tab.

Orang tua di Kelurahan

Rabadompu Timur sangat prihatin atas perkembangan zaman yang semakin modern.

Pada saat ini orang tua dituntut untuk bisa mendidik, membimbing, memberikan arahan yang sesuai dengan norma yang berlaku, namun di satu sisi pesatnya arus globalisasi lewat media seperti tayangan TV dan main tab sangat kuat memperngaruhi jiwa anakanak di Kelurahan Rabadompu Timur.

b. Pengaruh lingkungan sekitar.

Kedisiplinan anak dalam belajar juga dapat dipengaruhi oleh lingkungan disekitarnya, misalnya anak malas belajar karena lebih tertarik dengan ajakan temantemannya untuk bermain.

\section{Kesimpulan}

Berdasarkan data hasil penelitian, maka penelitian ini dapat disimpulkan sebagai berikut :

1. Pola asuh orang tua dalam meningkatkan disiplin pendidikan anak di Kelurahan Rabadompu Timur Kecamatan Raba Kota Bima adalah ditemukan 3 bentuk pola asuh yaitu pola asuh otoriter, permisif dan demokratif.

2. Kendala yang dihadapi oleh orang tua dalam mendidik kedisiplinan pendidikan anak-anaknya yaitu kendala intern (dari dalam keluarga) seperti kesibukan orang tua, kurangnya waktu berkumpul dengan keluarga. Sedangkan kendala ekstern (di luar keluarga) adalah berasal dari pengaruh pesatnya arus globalisasi misalnya tab dan televisi serta pengaruh lingkungan sekitar seperti teman sepergaulan anak. 


\section{Daftar Pustaka}

Balson, Maurice. 1987. Bagaimana Menjadi Orang Tua Yang Baik. Jakarta : Bumi Aksara.

Citrobroto Suhartini, 1980. Cara Mendidik Anak Dalam Keluarga Masa Kini. Jakarta : Bharata Karya Aksara.

Danny I Yatim. 1986. Kepribadian, Keluarga dan Narkoba. Jakarta : Ancan. Dewantara, Ki Hadjar. 1962. Buku I : Pendidikan. Jogyakarta : Majelis Luhur Taman Siswa.

Departemen Sosial RI. 1979. Undangundang Tentang Kesejahteraan Anak. Jakarta.

FJ. Monks, A.M.P. knoers, Sri Rahayu Haditono. 1998. Psikologi Perkembangan. Yogyakarta : Gajah Mada University Press.

Grisanti, M.E. 1990. Seni Mendisiplinkan Diri Anak. Jakarta : Mitra Utama. Gunarsa-Gunarsa. 1986. Psikologi Perkembangan Anak dan Remaja. Jakarta : BPK Gunung Mulia.

Gunarsa-Gunarsa.1995. Mendisiplinkan Anak Dengan Kasih Sayang. Jakarta : BPK Gunung Mulia.

Hurlock,1997. Psikologi Perkembangan : Suatu Pendekatan Sepanjang Rentang Kehidupan. Jakarta : Erlangga.

Kartini, Kartono. 1992. Usaha Orang Tua Dalam Rangka Mendidik Anak Usia Sekolah. Jakarta : Penerbit Rajawali.

Nasir Ali, M. 1975. Bagaimana Menjadi Orang Tua Yang Berhasil. Jakarta : Bina Aksara.

Martaniah Mulyani. 1964. Peranan Orang Tua Dalam Perkembangan Kepribadian. Yogyakarta : Jiwa Baru.
Miles Mattew B dan Hubberman A Michael. 1992. Analisis Data Kualitatif. Jakarta : UI Press.

Moleong, Lexy J. 2000. Meteodologi Penelitian Kualitatif. Bandung : Remaja Rosdakarya. 